\title{
Two Versions of Lah Bako Dance: Representing Agricultural Working Class and Identity Creation
}

\author{
Hery Prasetyo \\ Sociology Department, Universitas Jember \\ email: herypras.fisip@unej.ac.id \\ Dien Vidia Rosa \\ Sociology Department, Universitas Jember \\ email: dien.fisip@unej.ac.id. \\ Restu Puji Astuti \\ Sociology Department, Universitas Jember \\ email: restu.puji47@gmail.com \\ Ramadana Tahta Satria \\ Sociology Department, Universitas Jember \\ email: ramasatria358@gmail.com \\ Rifki Dwi Ramadani \\ Sociology Department, Universitas Jember \\ email: rifkidwiramadhani@gmail.com \\ Ayu Dinda Permata \\ Sociology Department, Universitas Jember \\ email: ayudinda1606@gmail.com \\ Sagita Dwi Ambarwati \\ Sociology Department, Universitas Jember \\ email: sagita.dwia@gmail.com
}

\begin{abstract}
This article discusses the politics of identity in dance representations. Lah Bako dance is one of the Jember icons that was created to build an image of the tobacco farmers' culture. This dance is performed by
\end{abstract}


women who represent the tobacco production process. However, the practical needs that are framed through aesthetic motions present a new form of how women are positioned in agricultural societies. In this context, the Lah Bako dance becomes an instrument to create new meanings for women and also becomes an imaginary space for tobacco farming. The article discusses two main points: first, the Lah Bako dance became an integral part of government's project to construct mass memories in the relations of production in the tobacco sector, and the second is women as subjects representing a farmer's spirit which is formed as a new figuration that fluid and changeable as political image that transcended existing experimental conditions. An addition point highlighted in this article was the emergence of Islamic values in a dance version which is accomodated the elite interest of Jember's identity slogan formation. Reseachers use Stuart Hall's cultural representation and ethnography method to narrate the identity. This research found that the Lah Bako dance is constructed in dominant cultural formations that are legitimized by the structure of the regional government bureaucracy. Furthermore, it is crucial to criticize the space for voicing farmers' subjectivity and class politics, which has been muddled from the elite network. The problem appears as a paradox for creating aesthetic reality through art, where the symbolic form can be enjoyed without touching inequality that continually arises.

[Artikel ini membahas politik identitas dalam representasi tari. Tarian Lah Bako merupakan salah satu ikon Jember yang diciptakan untuk membangun citra budaya petani tembakau. Tarian ini dibawakan oleh wanita yang mewakili proses produksi tembakau. Namun, kebutuhan praktis yang dibingkai melalui gerakan estetika menghadirkan bentuk baru bagaimana perempuan diposisikan dalam masyarakat pertanian. Dalam konteks ini, tarian Lah Bako menjadi instrumen untuk menciptakan makna baru bagi perempuan dan juga menjadi ruang imajiner untuk pertanian tembakau. Artikel ini membahas dua poin utama: pertama, tarian Lah Bako menjadi bagian integral dari proyek pemerintah untuk membangun ingatan massa dalam hubungan produksi di sektor tembakau, dan yang kedua adalah perempuan sebagai subjek yang mewakili semangat petani yang terbentuk sebagai gambaran baru yang berubah-ubah dan berubah sebagai citra politik yang melampaui kondisi eksperimental yang ada. Poin tambahan yang disorot dalam artikel ini yakni munculnya nilai-nilai Islam dalam versi tarian yang mengakomodasi kepentingan elit pembentukan slogan identitas Jember. Peneliti menggunakan representasi budaya Stuart Hall dan metode etnografi untuk menceritakan identitas. Penelitian ini menemukan bahwa tarian Lah Bako dibangun dalam formasi budaya dominan yang dilegitimasi oleh 
struktur birokrasi pemerintah daerah. Selain itu, sangat penting untuk mengkritik ruang untuk menyuarakan subjektivitas petani dan politik kelas, yang telah kacau dari jaringan elit. Masalah muncul sebagai paradoks untuk menciptakan realitas estetika melalui seni, yakni bentuk simbolis dapat dinikmati tanpa menyentuh ketidaksetaraan yang terus-menerus muncul.]

Keywords: Lah Bako dance; elite; politics of identity; representation; social formation

\section{Introduction}

Cultural dances that existed and developed in Jember were associated with issues of ethnicity. In this case, ethnicity is narrated as social groups that bring cultural formation and develop new social spaces. Moreover, it is the social formation that shape cultural identity in Jember are displayed in a pluralistic manner and contested to gain political legitimacy. In identity discourse, Jember was formed at least by Madurese, Javanese, Pendalungan, and Jemberan cultures. Each of those was trying to display its cultural character. The scholars characterized it as a hybrid identity. The term referred to Homi K. Babha's explanation about the emerging of a new culture detached from its origin. ${ }^{1}$

These assumptions are based on historical proof that since the colonial era, Jember was an area developed by the migrant working class. Today, Jember's social space is developing in line with modern culture, which has symbols that resemble cities such as modern malls, hotels, and so forth. Nonetheless, the current cultural form has not only marks the connection with the original culture that was brought by the working-class subject. ${ }^{2}$ The issue addressed is how the forms of cultural articulation able to make space for traditional forms to fuse with a modern spirit.

Differences that appear in the form of cultural articulations have been categorized as hybrid cultures dominated by Javanese and

\footnotetext{
${ }^{1}$ Jonathan Rutherford, "The Third Space: Interview with Homi Bhabha," in Identity: Community, Culture, Difference (London: Lawrence \& Wishart, 1998), 207-221.

${ }^{2}$ Besley Timothy, Persson Torsten, 2019. "The Rise of Identity Politics," Working paper, LSE and Stockholm University, http://www.lse.ac.uk/economics/Assets/Docu ments/personal-pages/tim-besley/working-papers/the-rise-of-identitypolitics.pdf.
} 
Madurese. Even though conceptually the hybrid culture argument needs to be critically reflected. Particularly, in the context of Jember culture, which has a plurality of the traditional roots and capital penetration that tried to absorb the subjectivity of Jember people. From the background, Lah Bako Dance is a case that marks the assumption of hybrid culture is not sufficient to narrate the political economy layer behind cultural articulation that is represented through aesthetic motions.

Meanwhile, the bureaucratic elite needs to create icons appropriate with the changed that happened in Jember. Therefore, the emergence of Lah Bako dance is a part of elite necessity. The idea of Lah Bako dance creation was to represent the structure of the agricultural economy and the daily lives of tobacco farmers. In this case, the contradiction that arises lies in how the working class with the complexity of the cultural articulation has to face will of the elite to represent the existence of the working class through a new dance. Although, this new dance is considered to strengthen and to unite the plurality of cultural communities, however, the arbiter motions that are displayed raise problems regarding the formation of Jember society.

Lah Bako Dance Art comes from the syllable "Lah" which means processing and "Bako", which means tobacco. These two syllables, "Lah Bako", can be interpreted as processing tobacco. ${ }^{3}$ Thus, Lah Bako Dance is a dance that describes the activities of farmers in processing tobacco. Dance is the movement of beauty. And the key to dance is how the movement can represent its meaning. Dance becomes a form of aesthetic language which symbolically displays meta narration in motion. ${ }^{4}$ In a political context, the aesthetic language displayed in dance will continue to be produced and reproduced socially to affirm the meaning that is predominantly

\footnotetext{
${ }^{3}$ Interviewed with Sulis on 29 August 2018 at Jember.

${ }^{4}$ Y. Smith, "Traditional Dance As A Vehicle For Identity Construction And Social Engagement After Forced Migration," Societies 8, no.3 (2018): 67; https://doi.org/ $10.3390 / \operatorname{soc} 8030067$
} 
shaped by the structure of the bureaucratic elite. Larasati noted, even such dances subdued by the state for the regime's interest. ${ }^{5}$

The elites in the setting of Lah Bako dance are subjects consisting of government institutions, groups, the arts community, and the people who accept Lah Bako dance as Jember's identity icon. Simultaneously, the crucial issue of this identity project is the problem of presenting a new reality of the farmers' culture, which later becomes part of identity contestation. This study argues that Lah Bako dance became a mission of governmental projects in representing a new tobacco image to neutralize the FCTC (Framework Convention on Tobacco Control) issue. Further, women as subject dancers representing a farmer's identity as a fluid political image.

In a theoretical conception, culture becomes the realm that appears dynamically were the new forms presented as articulation systems that are crossed by disputes. The dynamics inherent in the concept of culture presuppose actions between forces in society, which then constructing a cultural formation. ${ }^{6}$ Although deliberative communication relations can reduce issues of the contested form of power, yet, it cannot eliminate the politics of identity problems. Power relations, whether it assumes the dominant or subordinate position, may determine how the articulation moments will be interpreted as an essential part of subjectivity that can beyond the reach of the meaning of the culture being built. Base on the theoretical point of view, Lah Bako dance can be seen as how the power of the elite with their social network has successfully obscure the agricultural relations, particularly by giving the dynamic and romantical side of women's life.

\section{Methods}

This research uses an ethnographic approach based on cultural studies assumptions. The issue emphasized is the political issue of identity claimed as part of the representation of ethnicity. The

5 Rachmi Dyah Larasati, "The Dance That Makes You Vanish: Cultural Reconstruction in Post-Genocide Indonesia," Journal of the Humanities and Social Sciences of Southeast Asia 169, no. 4 (2013), doi:10.1163/22134379-12340060.

${ }^{6}$ Caroline Howarth, "Representations, Identity, and Resistance in Communication," in The Social Psychology of Communication, ed. Derek Hook, Bradley Franks, and Martin W. Bauer (London: Palgrave Macmillan UK, 2011), 153-168, doi:10.1057/ 97802302976168 . 
definition of ethnicity discursively refers to the issue of historicity and formation through power relations, while representations that are created and formed are part of meta narration intended to form the spaces of power.

The space of power that is specific is how dance can form an imagination about the relations of production in which it negates the production relations that present it. This study builds an identity political narrative in Lah Bako dance through oral history that represents the awareness of the informants, through observation, and discussion. Informants who are part of the development of this research include dance artists, academics, cultural activists, and tobacco farmers.

The information narrated by the informants becomes a part that is compared with the narrative about the culture of Jember then analyzed using a political representation model from Stuart Hall. Hall's idea introduces complex relations between materiality and objects that make up knowledge. ${ }^{7}$ Moreover, knowledge form becomes a representation system that creates a structure of consciousness. The structure of consciousness is part of the social formation which presupposes the existence of subjectivity that interpolates the presence of the subject. Empirically, the narratives raised by informants are part of the consciousness formed through social relations that practiced in everyday life. Again, in addition, to form informants' subjectivity narration and acknowledge their social background could nuances the dynamic of cultural formation created through their life. The research technique in analyzing refers to the method of Stuart Hall which does not only stop at the reflective and intentional stages. ${ }^{8}$ Both ways are seen to be naive in social relations if too focused on one stage. Furthermore, this study uses discursive social construction, which is a strategy to present the meta narration behind informants' subjectivity.

\section{Results}

\section{The Idea of Jember: Creating Identity Over Commodities}

7 Stuart Hall (ed.), Representation: Cultural Representations and Signifying Practices (London: SAGE Publication Ltd., 1997), 17.

${ }^{8}$ Ibid., 24-26. 
An oral historical narrative that develops and adheres to Jember as a cultural space at least can be categorized into two concepts. First, it related to the myth of the origin of Jember's naming. And second, it related to commodities that are the origin of the development of economic structures. The two categories that emerged in this study were placed as the starting point to discuss how Jember emerged as a cultural space that was to be claimed and displayed elitist character.

One narration that explains the origin of naming Jember is rooted in the word "Jembar" which means broad, which is then interpreted as land, expanse, or an extensive place that is between the mountains of Argopuro and Raung; has promised a new hope. ${ }^{9}$ Although it looks natural and represents natural conditions that are full of hope, behind the narrative leaves an ironic story about its territorial development. Jember was transformed into an area that could produce world-class tobacco meanwhile the sacrificing of its inhabitants in colonial periods was about disappeared along with the colonial heritage.

Other narrations told by the informants relate to the concept of the word "djembrek" which is interpreted as a muddy and soft soil condition. ${ }^{10}$ The two narrations inherent in Jember, whether interpreted as "jembar" or as "djembrek", are daily lives that are closely related to the working-class culture in Jember. Specifically, the mobilization of Madurese to fill the workforce needs that, at the same time, develops into a sociocultural structure. While Javanese came after the railway project. ${ }^{11}$ The assumption that these two cultural characters become dominant in Jember can be reflected in a more empirical context. Although there are claims by academics that the socio-cultural character inherent in the Jember community marks a mixture of Javanese and Madurese ethnicity, it does not mean that it can negate other ethnicities.

\footnotetext{
${ }^{9}$ Trijono, Djember 1859-1929: Melacak Sebuah Kota Berbasis Perkebunan di Jawa Timur (Denpasar: Cakra Press, 2011).

${ }^{10}$ Ibid.

${ }^{11}$ Nawiyanto, The Development of Plantation in Jember during the Late Colonial Period, 1859-1942 (Yogyakarta: Lembah Manah, 2008), http://repository.unej.ac.id/ handle/123456789/56309.
} 
Referring to other conceptions, namely those that are marginalized, and suggested to be negated, the historical research conducted by Margana about Blambangan is an example of other ethnicities in Jember. ${ }^{12}$ The transfer of Blambangan kingdom to an area that is administratively now referred to as Jember is part of the historical evidence of the existence of Osing ethnicity. Besides, it also includes Bugis, Arab, and Chinese ethnicities. Those pluralities of ethnic groups can be found and create social spaces in the urban areas of Jember or can be found in the suburbs of Jember.

The Jember communities have a variety of historical stories, even in each village they have folklore that presents their ethnicity awareness. There are also stories about the spiritual journey from the area of origin for discovering vast new areas and still untouched by humans. In other narrations, there is a myth developed in the Djember Chronicle, which also gives a unique social character to see what Jember is. The story of social conflict rooted in elite power and Islamization of Jember is a narration that was built in the Djember Chronicle, although this version not too popular among people.

This study looks at one mythological character in the historical narrative of Jember named Dewi Jembersari. This character is the only female character who has a place in the narrative of Jember. Trijono writes that Dewi Djembersari is a story of a princess who ran from her palace to an area untouched by human civilization and still in the condition of a wilderness. ${ }^{13}$ In the end, the goddess died, and the area that became her exile was called Jember by the followers of the goddess.

Through oral stories, Jember's historicity was shaped by the character of the heroism of the working class, lengthy material conditions, untouched and natural, Islamization, and social conflict. Those discourses are able to encourage imagination that saw the issue of the social class behind the creation of the Jember region. However,

\footnotetext{
12 Sri Margana, Ujung Timur Jawa, 1763-1813: Perebutan Hegemoni Blambangan (Yogyakarta: Pustaka Ifada, 2012), https://www.goodreads.com/book/show/1614 8406-ujung-timur-jawa-1763-1813.

${ }^{13}$ Trijono, Djember 1859-1929: Melacak Sebuah Kota Berbasis Perkebunan di Jawa Timur (Denpasar: Cakra Press, 2011).
} 
the limited female character in the Jember narrative is a contradiction to see gender issues which are displayed in dance arts.

The narration that develops in the community is different from those developed by the local government. In the official book produced by the Jember regional legislative, the issue raised emphasized the formation of an economic structure that originated from the opening of tobacco plantations. Through research and tracing historical evidence, the Jember regional legislative assisted by some academics tried to trace the Jember anniversary. In the study and later recorded by the regional legislative, Jember expressly accepted the formation of the political economy of the plantation and received the form of the distribution of awareness of its workers' classes. The receipt was marked by the Jember anniversary, which was determined through documents stating Jember to be a new plantation area apart from the Bondowoso plantation.

The narration of the working class seemed to face the narration of the legislative that acknowledged by local government becomes a circumference of how then the regional government as the bureaucratic elite determines its cultural identity. Although the local government accepted the character of the plantation area and the social settings of the working class, the government did not explicitly present working-class heroism as a narration that formed the structure of consciousness in Jember. The government relinquished the moment of recognition for small narratives about Jember and focused to form identities based on the welfare of its commodities.

Tobacco becomes a commodity that is explicitly displayed in the consciousness of the local government elite. Through an effort to produce a cultural representation of tobacco commodities, which began in the mid-80s, the government saw space to be filled by a new image of Jember. Cak Yit, a Jember artist, narrated the efforts to form cultural representation as part of government control over the Jember community. The presence of the government, with its authoritative power, is imagined to touch the complexity of social formation. Thus, the social structure placed the government as part of the elite. ${ }^{14}$

The Lah Bako dance which is produced as a cultural representation presents a paradox about Jember's identity formation.

${ }^{14}$ Cak Yit (a Jember artist) in discussion with the author, September 2018. 
First, the selection of women as dancers regardless of the aesthetic language that was intended to be built at that time, leaving gender issues forming a narrative about the territory of Jember. Second, the selection of commodity issues is quite shocking for the social formations, which reinforce the working class that is conditioned as a subject repressed by the dominant structure of plantations. Moreover, the local government elite naturalized it as an inherent part of the Jember region without narrating the political economy issues behind the dance. Third, the appearance of tobacco dance reduces the problem of working-class character, which in reality becomes part of the welfare production process, which leads to the creation of more value for investors. It is called the political economy of passion, in Savigliano (1995) concept to explain the transformation desire-passion into a new form of dancing capitalization.

\section{Re-creating The Lah Bako}

Historically, Lah Bako Dance emerged from the wishes of Jember regent Soerjadi Setyawan in 1985, who appointed Bagong Kussudiarjo, an artist and dance maestro from Yogyakarta, to make a dance that told about the tobacco processing. ${ }^{15}$ To achieve a connection with the working-class character, observation used as tools to recognize tobacco workers and farmers. The measurement was conducted at several warehouses and carried out for several months. Bagong Kussudiarja worked with several dancers from Jember, and one of the dancers named Yuni Budi Astuti or better known as mrs. Prayit. As a person who settled in Jember and had studied dance directly under the direction of Bagong Kussudiarja, Mrs. Prayit was believed to be able to give spirit and be able to present a representation of tobacco farmer culture. Although mrs. Prayit's name was not much discussed, she became one of the important figures who later developed Lah Bako dance in Jember.

Through Lah Bako dance the elite believed that Jember would have a distinctive art. This dance also has functioned as a representation of tobacco which visualizes the wealth of Jember. The

\footnotetext{
${ }^{15}$ Bagong Kussudiardjo, Dari Klasik Hingga Kontemporer (Yogyakarta: Padepokan Press in association with Bentang Pustaka \& Literary Agency, 1992).
} 
attempt to re-create tobacco dance is a social reproduction experiment, which tries to move the representation of power from those based on elite interests into a new form and marks the entry of the power of civil society for shaping cultural formation. Although the dances, which were created in the mid-80s and reproduced in the mid-2000s, were both initiated by the regional government elite. However, both have different characters and political settings. The $80 \mathrm{~s}$ were the era of the appointment of regents as regional leaders by the central government. While in the $2000 \mathrm{~s}$, the regent was democratically elected by people.

In its development, in 2007, the Regent of Jember named MZA Djalal ordered Sulis, an art teacher in one of Jember Public High Schools, to recreate the Lah Bako dance which represented the character of the Jember people. Both Bagong Kussudiarja and Sulis intended to build imagination about the character of Jember with the relation of production to the setting of tobacco farming. They received orders from the bureaucratic elite, namely the Regent, in each era. In the framework of cultural studies thinking, the elite's reproduce materiality in their domains and representation created in an era of leadership could present claims of identity politics.

The political setting provides a way to see how centralistic cultural representation becomes popular. As a concrete example, the initial version of Lah Bako dance was constructed by representing Yogyakarta-style women who used the palace bun and kebaya. The representation brought by the creator confirms the position of the aesthetic language, which is at the center or refers to Yogyakarta. While the second version represented women, who must change their cultural representation, this can be started from having to use a hat and or veil that represents Islam in Jember, a green garment that represents the color of tobacco, up to kebaya fabric which must represent Jember with tobacco motif batik. ${ }^{16}$

Sulis, the second version of Lah Bako dance creator, although not originally from Jember, has the spirit and ability to create new dances. She said, while she was observed at the tobacco warehouse, she saw the workers used a hat to cover their hair. Also, there were tobacco farmers who covered their heads with a cloth as protection from the sun. As a Muslim, she begun to connect the hat which was

${ }^{16}$ Sulis (a Lah Bako dance creator) in discussion with the author, September 2018. 
originally used functionally, changed to religious aesthetic character, which appropriates with the idea of ideal Muslim women. The new version of Lah Bako dance tries to conceptualize what should a woman wear, particularly in public space. Not only displaying a new form of the feminization of women's bodies but is also intended to create unique ideal inherent in working-class women. ${ }^{17}$ Research by Anoegrajekti about the transformation of 'Gandrung' Dance in Banyuwangi showed almost a similar model of women's appearance in art tradition supported by Islamic values. ${ }^{18}$

In this context, although Lah Bako dance is not a sacred or traditional dance, it is a formal and elitist dance that could be placed equally with other creative dances. At that point, formal and elitist dance becomes an optional dance for formal events and, at the same time, becomes a dance that can be negotiated by artists. The current negotiations lie in how artists have the option to play the Lah Bako dance according to the version believed to be Jember's cultural representation or instead choose to dance others. However, the commodification of female dancers and the daze of relations of production in agricultural communities became issues that seemed disappeared with the need to present a local identity.

\section{Forming Representation Through Dance}

The size of tobacco commodities in Jember is a rational argument for owning and elevating the tobacco theme into Jember's distinctive art. Women have been chosen to dance Lah Bako, which is formed to represent the structure of the political economy because most tobacco processing activities are carried out by them. Yet, it needs to be noted, the argument for the creation of Lah Bako dance is still a debate. Some say that Bagong created Lah Bako dance because he was invited by Jember artists who wanted to create art that raised the theme of tobacco. Moreover, other informants said that Jember artists desire to create works of art but are still unsure of developing what kind of art. Until now, there has been no clear narration about

\footnotetext{
${ }^{17}$ Mira (a Lah Bako dancer) in discussion with the author, September 2018.

18 Novi Anoegrajekti, "Gandrung Banyuwangi: Pertarungan Pasar, Tradisi dan Agama Memperebutkan Representasi Identitas Using," (PhD diss., University of Indonesia, 2006).
} 
why Bagong, who is a Central Javanese artist, created the Lah Bako dance.

Sulis believed that she has to present the character of the Jember people based on her experience in the field of dance. Transform the classical Lah Bako and made a new motion to display the spirit of Jember. Thus, Lah Bako dance currently has two versions, namely the original version created by Bagong and Sulis's version.

Two Lah Bako dance versions have some differences. The differences between them lie in the tempo of music, motion, and costume. In the Lah Bako dance created by Bagong, it has a slower pace of the music; its movements are smoother and softer. In Sulis's Lah Bako dance, the rhythm of the music is faster, and the sound of the music is louder than the classical one, and the movements are more rapid than the previous one created by Bagong. In other words, Sulis's Lah Bako dance tends to be more energetic and claimed to be able to represent Jember people. Although there are differences from the original version or the Bagong version, Sulis's version of the Lah Bako dance tobacco farming is still the same as the Bagong version in terms of representing the spirit of tobacco workers. ${ }^{19}$ It needs to be underlined that the problem of the new meaning that has been displayed is not intended to change the idea of humans as subjects but to emphasize how humans should live dynamically and follow the ideality that came from the social structure.

The Lah Bako dance from Sulis' version emphasizes the character of the firm and hard Madurese. She created his version of Lah Bako dance by looking at the reality that $75 \%$ of the people of Jember were Madurese. Although her claimed need to be compared with the real data. However, what it did not realize was the fact that The Jember community then stigmatized as a Madurese community. The consequences were the cultural formation that has thrived was also considered to be a Madurese culture, and further, more tobacco workers in Jember were mostly Madurese. Sulis believed that Lah Bako dance has to represent characteristics of Jember people, which are based on the characteristics of the hard and firm Madurese people. Still, the strict and assertive meaning of Lah Bako dance is a form of

\footnotetext{
${ }^{19}$ Karsono (a musical player for Lah Bako dancer) in discussion with the author, September 2018.
} 
praise about the Madurese who are diligent, active, and hard-working at work.

Even though the Sulis version of Lah Bako dance tends to refer to the character of the Madurese, it did not mean that this dance does not show the Javanese character. Lah Bako dances in an original version of Bagong, with slow and soft movements also tempo, which better describes the Central Javanese people who are famous for their subtle rules. Meanwhile, Sulis's version of Lah Bako dance adopts the Javanese character side with a movement that displays the softness side and is described as a Javanese character. Again, what Sulis made was constructed in the hybrid culture, a combination of Javanese and Madurese. However, Sulis Lah Bako's dance is still dominated by the portrayal of the character of the Madurese who is firm and hard.

The costumes of each two versions of Lah Bako dance have differences and similarities. For example, the costume version of Bagong's Lah Bako dance wearing by a dancer is a light green kebaya with the hair on the bun using three embellishments such as red, yellow, and green and also wear earrings and other decorations. Then at the bottom using a long cloth and apron. While the costume used in Sulis's Lah Bako dance performed in a dark green kebaya, while on the head using a hat, and at the bottom using a long cloth. Then, in the stomach, there is a cloth that is used as a belt.

Each costume attribute has its meaning. The first difference seen from Sulis's Lah Bako dance version is from the hairstyle. In the first version of Lah Bako dance, the version of the dancer's hair is the bun. Meanwhile, Sulis's Lah Bako wears a hat. Not only it was designed with specific exhibit but the entire Lah Bako Sulis dance costume itself designed, including batik designs on long fabrics or sarongs to represent tobacco. The design of a hat like a mountain in the Lah Bako dance costume has a meaning that presenting Jember, which located between two mountains.

These two versions of the Lah Bako dance show the pressure points that mark how dominant culture is accepted and articulated. The re-creation carried out by Sulis presented an affirmation of the authenticity of Jember which she claimed as Madurese. The essential problem is the emphasis of reversing the character of Jember, which no longer refers to Yogyakarta as a cultural center then transformed 
into a local character with the imagination of the working class. Repeatedly, although the reversal of cultural meaning has been carried out, it still has not touched the plurality of cultural entities that are spread in Jember.

\section{Discussion}

\section{Legitimation through Social Networks}

Lah Bako was danced at a formal event and was introduced to the school. One of the schools that studies Lah Bako dance is SMAN 2 (senior high school) Jember. Lah Bako dance, which is often shown today in Jember is Lah Bako dance by Sulis's creation. Lah Bako's dance by Sulis has been displayed on formal occasions, such as welcoming events or opening events by both the local government and other institutions. It was argued that Sulis was trusted by the regent of Jember to renew Lah Bako dance with the character of the Jember people. By presenting the character of the Jember people, Sulis's Lah Bako dance was received by the Jember community. Also, Sulis had close relations with the elite long before Lah Bako's creation, namely when she was trusted to make other artistic creations.

Sulis's relationship with the elite who have power makes Lah Bako is easy to be accepted because it brings new power. Therefore, those who know Lah Bako dance are more familiar with Sulis' Lah Bako dance version than the Bagong version. This assumes that Sulis's Lah Bako fame is derived from the intensity of her appearance and promotion in the dance competition. People more often see the Sulis version of Lah Bako dance because the regional government and agencies support and compare the dance as a regional icon.

While the Bagong Lah Bako dance still gets space in the art of Jember dance. There was an art studio that still carried the Bagong version of Lah Bako and chose to dance it on shows. In other words, not all dance studios in Jember use the Sulis's version. One of the studios that still chose to use the original version of Bagong revealed that the choice was a form of respect and effort to respect the creator of Lah Bako's original dance, Bagong. The argument about originality or origin reinforces the reason that Bagong's Lah Bako version still will be used as Lah Bako dance even though there is no Bagong that creates the dance. 
Although Lah Bako dance has been around since the mid1980s and again in 2007 was re-presented with a creation version that showed more the character of Jember people, but some people in Jember still did not know or knew that there was a dance that told about tobacco farmers, namely Lah Bako dance. Especially people who live in non-urban or rural and highland areas. Lah Bako dance only develops among the elite because it is often performed informal and formal events. As for non-formal events, this dance is rarely or not even performed.

The creation of Lah Bako dance aims to compare and become an icon that Jember is a well-known tobacco-producing region, especially in the 1960s and 1970s. On the other hand, Lah Bako dance aims to appreciate tobacco farmers. However, this is not in line with the initial goal because today's tobacco discourse makes Jember an area that experiences commodity-based identity crises. Meanwhile, the goal of appreciating tobacco farmers also failed because farmers did not know if there was a dance that raised the tobacco theme. The paradox is assumed because Lah Bako dance can only be enjoyed by the elite and does not develop in the community. For instance, in local village events. Thus, it can be assumed that there was no significant progress in Lah Bako dance among the Jember community.

\section{Social Workers Formation: Politics of Spaces in the Frame of Dance}

In the area of Jember, which has the nickname of the City of Tobacco, women are the spearhead of the economy produced from tobacco leaves. During the tobacco season, women are often found in fields and tobacco processing warehouses to work as laborers. Women are involved in the work process of tobacco cultivation, especially in post-harvest periods, from picking tobacco leaves, bringing to the warehouse, drying, sorting, and packaging. ${ }^{20}$ Women, in empirical site work to support the economy of their families. Lah Bako dance was created and became a traditional Jember dance. The dance was danced by a group of female dancers with rhythmic musical accompaniment, describing women who worked hard in tobacco plantations.

${ }^{20}$ Fera (a Lah Bako dancer) in discussion with the author, September 2018. 
Tobacco is the central theme raised in Lah Bako dance. Today, there are two Lah Bako dance versions, the original or the initial version made by Bagong and the Sulis version. Regarding dance tempo, the Bagong version is slower than Sulis. The speed of the dance version of Sulis is considered to represent Jember farmers, the majority of whom are Madurese. ${ }^{21}$ Furthermore, Sulis stated that the Madurese people worked hard and hard-working types. Therefore, Sulis made the Lah Bako version more energetic regarding its movements and music. Madurese ethnicity has quantitatively created the form of a narrative to legitimize what is presented through Sulis's Lah Bako dance. Although the impression of stigmatization of ethnicity is raised, it becomes vague because it is not readily explained and only appears in the aesthetic language of dance.

The claimed leaves the problem of whether the figures raised are part of the structure of the political economy. It becomes important to dismantle the issue of ethnicity which is formed through social relations and forming the structure of the political economy. ${ }^{22}$ The issue of the number will present the issue of representation and access to dominant ethnicity, especially in the era of participatory political post-reform. In the context of Jember and through dance representation, this contradiction becomes an important issue to be reflected. Such as when it is viewed from the structure of the working class and BPS Jember data, the pockets of poverty and illiteracy rates are still in the categorized area inhabited by ethnic Madurese.

An urgent issue does not lie in how this dance represents the ethnic Madurese. Nevertheless, how did the elite accept the representation formed on Jember and precisely the conditions of the working class in Jember without a strategy to build access to the ethnic Madurese. Meanwhile, the issue of plurality awareness of Jember, which eliminated non-Javanese and Madura cultural articulation forms, should be dismantled to see how Jember became part of inclusive social space.

${ }^{21}$ Sulis (a Lah Bako dance creator) in discussion with the author, September 2018.

22 Lito Tsitsou, "Dance, Class and The Body: A Bourdieusian Examination of Training Trajectories Into Ballet and Contemporary Dance," Scottish Journal of Performance 1, no.2 (2014) 63-89. doi: 10.14439/sjop.2014.0102.05 
The Lah Bako dance has not been widely known by the people of Jember in rural areas formed through the working class of the agricultural sector. While Lah Baco dance used to welcome guests to formal and informal events, both at official events or educational institutions, it becomes social spaces that are built and appear to separate themselves from the empirical conditions of the working class. In the theoretical context, what happens is the condition of modernity that forms a separation between social spaces through the autonomy of subjectivity.

The separation between representation and the subject represented in Lah Bako dance production arises not only from how this dance is consumed and produced in cultural spaces, which in this context are formal bureaucratic and academic spaces. Nevertheless, it also becomes part of the separation between the relations of agricultural production. The emergence of criticism in reading the representation of the working class of tobacco farming is a sign that behind this dance there is a problem of capital formation.

Categorically, tobacco plantation can be seen from the type of tobacco. It has different consequences. Na-Oogst tobacco leads to the international market, and Kasturi tobacco leads to the local market. Both of these commodities have different production relations. While in Lah Bako dance, both are obscured and formed uniformly.

Lah Bako dance, which imagines the representation of the working class of agriculture becomes pride and is enjoyed as entertainment. In practice, this dance is enjoyed by local government elites, academics, and those who imagine themselves attached and become part of the elite structure. With the claim to introduce Jember typical dance to guests who come from outside the region, at graduations, seminars, and other formal events, this dance is a form of celebration and play of the cultural identity of the agricultural working class.

The political representation of identity narrated by the Lah Bako dance is a contribution to the cultural formation in Jember. It is a kind of esthetic language that is constructed and formed based on awareness and knowledge about Jember. For Hall, the process of 
producing and marking identity politics is a power relation. ${ }^{23}$ In this case, the related subject is the maker of the Lah Bako dance, the government, and the community, especially tobacco farmers represented by the dance. The relations between the three led to unbalanced representations where farmers became subordinated parts.

The statement stressed that the agricultural working class is unable to interpret dances that describe the subjectivity of farmers. The desire of farmers to be given attention by the government is an exact condition from the voice of farmers. For farmers, the representation of the structure of the political economy through Bako Lab dance is not a fundamental part that can provide space and social access.

Social access is the concern to farmers intended as a form of real protection from the power of capital, which currently haunts the existence of farmers. Empirically, the issue of tobacco restrictions is a problem faced by farmers. Whereas the determination of tobacco prices, which openly cannot be accessed by farmers, becomes a problem that the government should strive to create wealth for tobacco farmers. In this case, representing the working class of farmers without protecting farmers from capital penetration is a paradox for the survival of tobacco farmers. Jember gets special attention because it has a socio-cultural area with a landscape that represents a variety of social communities. The issue of Jember iconic identity with the claim of Pandhalungan culture is a point to begin tracing the conceptual framework that marks internal issues. The elemental problem lies in how Jember is reduced to become part of cultural harmony. Regarding the harmonic that claimed they are the hidden struggles that need to be considered. Through the Lah Bako dance, this research finds conceptual framework that narrate the development of culture in Jember.

\section{Conclusion}

Based on the Lah Bako dance, what has present are the struggles that includes: first, confronts Javanese and Madurese culture. Second, it places the regency's city setting as the center of the struggle for cultures representation imagined as fluid and complementary.

23 Stuart Hall, Representation: Cultural Representations and Signifying Practices (London: SAGE Publication Ltd, 1997). 
Third, through Pendalungan cultural settings that negating the issue of elitism hiding behind functionally thought-out cultural narratives. Fourth, affirming the culture of the new working class with the complexity of the production relations that present it. Furthermore, the fifth, creating new cultural articulations. This development marked the need for a critical and discursive frame of mind that could be used to narrate new social formations in Jember.

Regarding what this research has argued, dance as an aesthetic language is produced through a process of tagging that is built through knowledge and legitimacy through power relations. Cultural space that arises and follows power relations is part of how the dance is performed or reproduced. In the context of this research, Lah Bako dance as a representation of the tobacco farming working class was presented to create a cultural identity in the Jember region. As a cultural identity, this dance is intended to construct social awareness and accept the concept of Jember as a city of tobacco.

Lah Bako dance is performed in cultural space and formed into two narratives. One narrative refers to the process of art production, which is centered on the centrum of Javanese culture. And the other is developed into Jember cultural space. The narration, which was later referred to as the version of the Lah Bako dance, confirmed a different identity and voice changes in social conditions in Jember. The initial version which put forward female characters who appeared softly was challenged by the movements and appearance of women who claimed to be Islamic and Madurese. It is a problem that appears in the aesthetic layer and appears in contestation to win over the legitimacy of the people of Jember.

Theoretically, cultural identity as dynamic, fluid, and continuously changing needs to be reflected. In particular, the problems inherent in the agricultural working class are being represented in dances and objectification as Jember's identity. The discourse that began with the issue of access to production and market relations to the protection of farmers from tobacco restrictions became one of the challenges that would reshape the representation of Jember and Lah Bako dance as icons of Jember.

\section{Bibliography}


Anoegrajekti, Novi. "Gandrung Banyuwangi: Pertarungan Pasar, Tradisi, Dan Agama Memperebutkan Representasi Identitas Using." PhD dissertation, University of Indonesia, 2006.

Besley Timothy, and Persson Torsten. 2019. "The Rise of Identity Politics.” Working paper. Accessed July 20, 2019. http://www. lse.ac.uk/economics/Assets/Documents/personal-pages/timbesley/working-papers/the-rise-of-identity-politics.pdf.

Hall, Stuart, ed. Representation: Cultural Representations and Signifying Practices. London: SAGE Publication Ltd., 1997.

Howarth, Caroline. "Representations, Identity, and Resistance in Communication." In The Social Psychology of Communication, Edited by Derek Hook, Bradley Franks, and Martin W. Bauer. London: Palgrave Macmillan UK, 2011. doi:10.1057/97802 30297616_8.

Kuntowijoyo. Perubahan Sosial Dalam Masyarakat Agraris: Madura 1850-1940. Yogyakarta: Mata Bangsa, 2002.

Kussudiardjo, Bagong. Dari Klasik Hingga Kontemporer. Yogyakarta: Padepokan Press in association with Bentang Pustaka \& Literary Agency, 1992.

Larasati, Rachmi Dyah. "The Dance That Makes You Vanish: Cultural Reconstruction in Post-Genocide Indonesia." Journal of the Humanities and Social Sciences of Southeast Asia 169, no. 4 (2013). doi:10.1163/22134379-12340060.

Margana, Sri. Ujung Timur Jawa, 1763-1813: Perebutan Hegemoni Blambangan. Yogyakarta: Pustaka Ifada, 2012.

Nawiyanto. The Development of Plantation in Jember during the Late Colonial Period, 1859-1942. Yogyakarta: Lembah Manah, 2008.

Rifai, Mien Ahmad. Manusia Madura: Pembawaan, Perilaku, Etos Kerja, Penampilan, Dan Pandangan Hidupnya Seperti Dicitrakan Peribahasanya. Yogyakarta: Pilar Media, 2007.

Rochana, Totok. "Orang Madura: Suatu tinjauan Antropologis." Humanus 11, no. 1 (2012): 46. doi:10.24036/jh.v11i1.622.

Rutherford, Jonathan. "The Third Space: Interview with Homi Bhabha." In Identity: Community, Culture, Difference, 207-21. London: Lawrence \& Wishart, 1998.

Savigliano, Marta. Tango And The Political Economy of Passion. Colorado: Westview Press, 1995. 
Smith, Yda J. "Traditional Dance As A Vehicle For Identity Construction and Social Engagement After Forced Migration." Societies 8, no.67 (2018): 1-10. doi:10.3390/soc8030067.

Trijono. Djember, 1859-1929: Melacak Sebuah Kota Berbasis Perkebunan Di Jawa Timur. Denpasar: Cakra Press, 2011.

Tsitsou, Lito. "Dance, Class and The Body: A Bourdieusian Examination of Training Trajectories Into Ballet and Contemporary Dance." Scottish Journal of Performance 1, no.2 (2014): 63-89. doi: 10.14439/sjop.2014.0102.05. 